
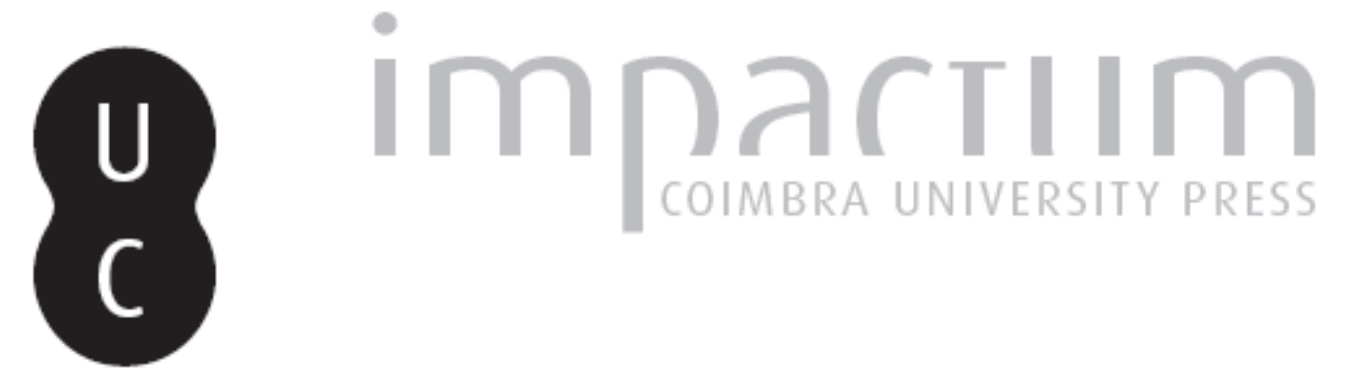

\title{
A difícil luta pela sobrevivência: a Misericórdia de Vila Viçosa durante a Monarquia Constitucional
}

Autor(es): $\quad$ Araújo, Maria Marta Lobo de

Publicado por: Centro de História da Sociedade e da Cultura

URL persistente:

URI:http://hdl.handle.net/10316.2/39529

DOI:

DOI:http://dx.doi.org/10.14195/1645-2259_10-2_3

Accessed : $\quad$ 26-Apr-2023 15:17:27

A navegação consulta e descarregamento dos títulos inseridos nas Bibliotecas Digitais UC Digitalis, UC Pombalina e UC Impactum, pressupõem a aceitação plena e sem reservas dos Termos e Condições de Uso destas Bibliotecas Digitais, disponíveis em https://digitalis.uc.pt/pt-pt/termos.

Conforme exposto nos referidos Termos e Condições de Uso, o descarregamento de títulos de acesso restrito requer uma licença válida de autorização devendo o utilizador aceder ao(s) documento(s) a partir de um endereço de IP da instituição detentora da supramencionada licença.

Ao utilizador é apenas permitido o descarregamento para uso pessoal, pelo que o emprego do(s) título(s) descarregado(s) para outro fim, designadamente comercial, carece de autorização do respetivo autor ou editor da obra.

Na medida em que todas as obras da UC Digitalis se encontram protegidas pelo Código do Direito de Autor e Direitos Conexos e demais legislação aplicável, toda a cópia, parcial ou total, deste documento, nos casos em que é legalmente admitida, deverá conter ou fazer-se acompanhar por este aviso.

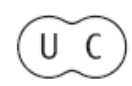




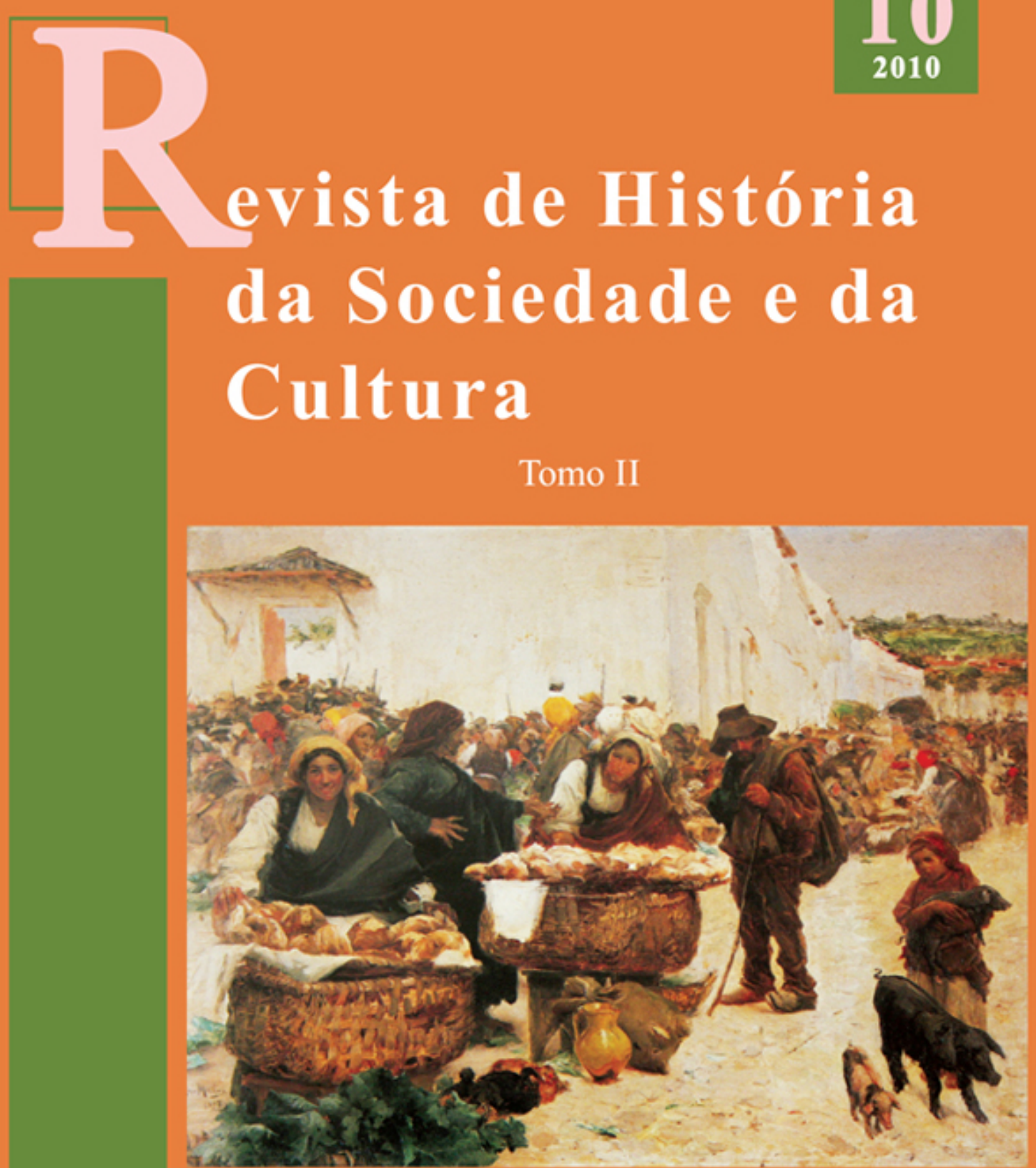

Centro de História da Sociedade e da Cultura Universidade de Coimbra

Coimbra 


\title{
A difícil luta pela sobrevivência: a Misericórdia de Vila Viçosa durante a Monarquia Constitucional
}

\author{
Maria Marta Lobo de Araújo \\ Docente do Departamento de História da Universidade do Minho \\ Membro do CITCEM \\ martalobo@ics.uminho.pt \\ Texto recebido em/ Text submitted on: 28/02/2010 \\ Texto aprovado em/ Text approved on: 19/04/2010
}

\section{Resumo/Abstract:}

O nosso trabalho procura analisar o desempenho da Misericórdia de Vila Viçosa durante a Monarquia Constitucional, demonstrando o estado de penúria em que esta confraria se encontrava e a luta por si travada pela sobrevivência. Com receitas minguadas, mas sobretudo com cobranças muito difíceis e despesas em crescimento, principalmente no sector da saúde, a Misericórdia foi obrigada a efectuar cortes em vários sectores da sua actividade, concentrando a sua atenção no hospital, não conseguindo evitar, todavia, as ameaças de encerramento em diversas ocasiões. A conjuntura política nacional e o seu reflexo no quotidiano da instituição contribuíram também para agudizar a instabilidade em que a instituição se encontrava. A Misericórdia sobreviveu, mas teve de desenvolver uma luta feroz para se manter em actividade.

Our paper seeks to analyse the performance of the Misericórdia - charity and welfare institution - of Vila Viçosa during the Constitutional Monarchy, and highlights the state of impoverishment of this brotherhood and its fight for survival. In the wake of reduced income, especially with collection constraints and growing expenditure, in the health sector in particular, the Misericórdia was forced to make cuts in several sectors of its activity, while concentrating its efforts in the hospital and facing on several occasions the threat of closing. National political events and their impact on the institution's operations caused it even greater instability. The Misericórdia survived, but was forced to fight a fierce battle.

Palavras chave/Keywords:

Misericórdia; Vila Viçosa; Crises; Monarquia Constitucional.

Misericórdia; Vila Viçosa; Crises; Constitutional Monarchy. 


\section{Introdução}

A história da Santa Casa de Vila Viçosa é longa e encontra-se profundamente marcada pela Casa de Bragança. Sem se conhecer a data da sua fundação, sabe-se que estava em funcionamento em 1510, quando o duque D. Jaime ordenou a passagem do hospital do Espírito Santo para a sua administração.

Nos 500 anos de existência assistiu a boas e más fases, a momentos de expansão e contracção, mas nunca até então tinha experimentado um período tão alargado de depressão e crises como o conhecido durante a Monarquia Constitucional.

Situada na sede da Casa de Bragança, esta confraria recebeu desde sempre o maior apoio dos duques, seus senhores, designados, durante toda a sua história, pelos irmãos como fundadores, provedores e protectores. As fontes não permitem afirmar se foram os seus fundadores, embora não duvidemos que de uma ou de outra forma estivessem presentes no momento da sua criação. Quanto a terem sido provedores, só existe menção da presença de D. Filipe, no ano de 1598-1599, na provedoria, mas sobre a protecção que dispensaram à Misericórdia, a documentação comprova-a em toda a sua extensão. Desde D. Jaime, passando por D. Teodósio I, D. João I, D. Teodósio II e D. João II, todos os duques e duquesas dedicaram um especial carinho à Misericórdia da vila. Não apenas fizeram transitar instituições que tinham criado para a Misericórdia, como aconteceu com o hospital do Espírito Santo, em 1510, o "hospital dos males", em 1611 e o colégio dos meninos órfãos, em 1558, como a coroaram de benefícios durante a vida e depois das suas mortes. Deixaram-lhe muitos legados para todas as suas áreas de acção, mas principalmente dotaram-na de um capital simbólico que lhe confere singularidade no panorama das Misericórdias portuguesas ${ }^{1}$.

Embora os senhores da Casa de Bragança tivessem um apreço especial pela Misericórdia da sede da sua Casa, a acção que desenvolveram nas Santas Casa do seu senhorio, apesar de ter sido mais interventiva nas terras

1 Para este assunto consulte-se ARAÚJO, Maria Marta Lobo de - Dar aos pobres e emprestar a Deus: as Misericórdias de Vila Viçosa e Ponte de Lima (séculos XVI-XVIII). Barcelos: Santa Casa da Misericórdia de Vila Viçosa; Santa Casa da Misericórdia de Ponte de Lima, 2000, p. 172-173. 
alentejanas, procurou acompanhar a acção da Coroa em período de reforma da assistência em Portugal².

O poder dos duques na Santa Casa de Vila Viçosa era tão grande e de tamanha profundidade que a confraria mais parecia uma sucursal da Casa de Bragança. Os duques ordenavam, despachavam para se cumprir, ditavam formas de governação, mandavam gastar para eles pagar, nomeavam assalariados, ordenavam a escolha de certos homens nas eleições para ocuparem os principais cargos, etc. Cumpriam-se as ordens dos duques em todos os sectores de actividade.

Com a sua partida para Lisboa em 1640, a Misericórdia perdeu o patrocínio directo e a presença física dos duques que a tornavam mais forte e favoreciam o seu desenvolvimento. Apesar do forte arrepio que sentiu, a relação de proximidade manteve-se durante o reinado de D. João IV, também ele seu irmão. Após a sua morte e com uma relação mais distante com os seus descendentes, a Misericórdia conheceu um período diferente, por não poder contar com o patrocínio directo dos duques, agora reis, mas também porque se viu desfalcada dos seus principais homens, que integravam a corte ducal e partiram com D. João II, futuro rei D. João IV para Lisboa. Por outro lado, viu-se envolvida na laboriosa e desgastante tarefa de curar militares no seu hospital.

À semelhança das restantes Misericórdias, conheceu no século XVIII, sobretudo na segunda metade, sinais de uma crise que se mostrará muito mais intensa na centúria seguinte: quebra nos legados ${ }^{3}$, problemas internos no sector dos assalariados, fraudes eleitorais, crise na cobrança de foros, rendas e pensões, enfim, desprestígio e pouco dinheiro. Na última década de Setecentos, a guerra Peninsular abalou a confraria, quando viu novamente o seu hospital encher-se de homens do exército. A sua situação geográfica e as lutas travadas no Alentejo tornaram a fronteira de Elvas frágil e aumentaram

2 Veja-se para esta matéria ARAÚJO, Maria Marta Lobo de - As Misericórdias quinhentistas do senhorio da Casa de Bragança. In Actas das II JORNADAS SOBRE AS MISERICÓRDIAS QUINHENTISTAS. Penafiel: Câmara Municipal de Penafiel, 2009, p. $35-58$.

3 A propósito da legislação pombalina e das suas repercussões nestas instituições leia-se LOPES, Maria Antónia - A Intervenção da Coroa nas Instituições de Protecção Social de 1750 a 1820. Revista de História das Ideias, volume 29 (2008) 136-140. 
as necessidades de a defender, bem como as terras vizinhas. Como se não bastasse, as invasões francesas prolongaram a presença do corpo do exército, porque a vila foi invadida.

Desde o século XVII que a confraria estava habituada à presença de militares, quer como doentes, quer como irmãos e até como gestores, mas nunca lidou muito bem com os atrasos nos pagamentos, devido à cura dos seus homens no hospital, que o exército teimava em arrastar. $\mathrm{O}$ desgaste causado nos confrades era muito grande e a falta de ingressos passou a ser gritante após a instalação do governo Liberal.

De um período de fulgor e protecção inicial que se prolongou entre 1510 e 1656, passou a um outro de menor esplendor e com sinais de crise, na segunda metade do século XVIII e duas primeiras décadas do século XIX, para finalmente mergulhar numa crise profunda, apenas com salpiques de alívio, como foram parte das décadas de 70 e 80 de Oitocentos, até à instauração da República.

Os quase 100 anos de Monarquia Constitucional pautaram-se por uma luta feroz de sobrevivência, sendo a confraria amparada em muitos momentos pelos mesários e mesmo assalariados, pagando dos seus bolsos algumas despesas da instituição, por esta estar praticamente falida. Por outro lado, alguns governadores civis mais contemplativos e diligentes, anuíam aos seus pedidos. Finalmente, uma vez mais a Casa de Bragança, sob a forma de Casa Real, ia amparando como podia a confraria, visitando-a e deixando marcas da sua presença. No século XIX e inícios do seguinte, D. Maria II, D. Pedro V, D. Luís, D. Carlos e D. Amélia regressaram a Vila Viçosa e acarinharam novamente a Santa Casa. As visitas de D. Carlos e de D. Amélia tornaram-se mais frequentes à vila e $\mathrm{D}$. Amélia esteve por várias vezes na Misericórdia, tornando-se desejada e muito acarinhada. A rainha fazia gosto em estar entre os confrades, em conviver com os empregados e em falar com os doentes, enquanto a sua presença alimentava uma forma de humanismo e filantropia que os irmãos desejavam imitar.

Com a passagem destes monarcas pela Santa Casa vieram também as doações, marcando uma nova fase da confraria. Numa situação muito difícil, os irmãos pediam ajuda aos monarcas, que nunca deixaram de os socorrer. Embora em tempos bem distintos, as ajudas recebidas não resolviam os problemas da instituição como anteriormente, mas conferiam-lhe novamente 
força anímica e deixavam marcas da Casa Real, avivando o patrocínio e o prestígio de uma instituição em luta pela sobrevivência.

Foi a mudança política, ocorrida em 1820, que causou pequenos e grandes sobressaltos à Santa Casa. Em primeiro lugar, desde logo, pelo seu alinhamento ao lado de D. Miguel. A análise da notícia exarada em acta de vereação, em 1828, da chegada de D. Miguel é bem demonstrativa do apoio e dos seguidores que tinha na vila ${ }^{4}$. Elogiado como um herói, este filho de D. João VI era visto em Vila Viçosa como o salvador, que era preciso apoiar.

Os confrontos entre liberais e absolutistas terão eco muito vivo na Santa Casa e tal como no panorama nacional, os ânimos só se acalmaram na década de 50. Posteriormente, serão os efeitos do rotativismo partidário e do republicanismo a causarem instabilidade na confraria.

Com enormes gastos no sector da saúde, dependente de foros e rendas que não cobrava por falta de capacidade financeira dos foreiros, sem a comparticipação financeira da Casa de Bragança, com gestões ruinosas e pouco interventivas e fustigada pelos ventos liberais que a obrigaram a profundas mudanças, a Santa Casa entrou num período de quase um século em que foi confrontada várias vezes com a ameaça de fechar as portas.

\section{Os modelos de gestão}

A Misericórdia governava-se desde 1806, como todas as suas congéneres, pelo compromisso de 1618 da Misericórdia de Lisboa, mas rapidamente se percebe que não se respeitava, desde logo no processo de escolha dos corpos gerentes, matéria de grande sensibilidade em todas as instituições. Em 1810, a Mesa reuniu-se para equacionar a permanência dos mesmos irmãos na direcção dos destinos da Casa no ano seguinte, pois todos tinham "mostrado grandeza no serviço da mesma". A questão colocava-se enquanto não chegava a resposta do monarca sobre um pedido que lhe tinha sido dirigido pelo escrivão para proceder a novas eleições, uma vez que o provedor estava ausente no estrangeiro e o escrivão-provedor encontrava-se já cansado,

4 Arquivo Municipal de Vila Viçosa (doravante AMVV), Livro para os Autos de vereação da Camara de Villa Viçoza 1827-1828, nº 814/VE. 79, fls. 26-27. 
mas não sabia como proceder, devido ao provedor ser vitalício. Esta figura não estava contemplada no compromisso, mas por ter sido designada pelo regente, ninguém ousava contrariar.

Depois de resolvida a questão, a normalidade regressou até 1820 . Com a criação dos governos civis pelo Estado Liberal, em 1834, a sua acção começou a sentir-se nas misericórdias. Em Novembro de 1835, o administrador do concelho de Vila Viçosa, cumprindo uma directiva do governador civil, pediu à Misericórdia o envio, com a maior urgência, dos livros de receita e despesa, o compromisso e os tombos. A Santa Casa enviou 6 livros de tombos e um livro de receita e despesa, iniciado em $1828^{5}$. Em curso estava uma estratégia de averiguação e controlo por parte do Estado a estas confrarias, conferindo enorme visibilidade aos administradores dos concelhos, governadores civis e juntas de distrito ${ }^{6}$.

A esta solicitação seguiram-se outras para procurar conhecer a situação financeira da instituição. Os pedidos do governador civil de Évora vinham na sequência da portaria de 2 de Setembro de 1838 que ordenava a todos os representantes do poder central que tomassem contas aos hospitais, misericórdias e a outros estabelecimentos pios. O Estado visava eliminar os abusos e a má gestão que grassavam em muitas destas instituições e dotou os seus agentes de poderes para poderem intervir e proceder a alterações na sua administração. Procurava pôr cobro às deficientes administrações que se perpetuavam em muitas misericórdias, desfalcando o seu património ${ }^{7}$. O Estado, através dos seus agentes, implementava uma gestão mais rigorosa e eficaz, colocando pessoas consideradas capazes de uma administração menos perdulária ${ }^{8}$.

5 AMVV, Fundo da Misericórdia, Livro de actas 1823-1839, fls. 28v.-29.

6 Veja-se para este assunto LOPES, Maria Antónia; PAIVA, José Pedro - Introdução. In PAIVA, José Pedro (coord. científico) - Portugaliae Monumenta Misericordiarum. vol. 8. Lisboa: Centro de Estudos de História Religiosa; União das Misericórdias Portuguesas, 2010, p. 8.

7 Sobre o desmazelo da administração da Misericórdia de Mértola veja-se FERREIRA, Manuel Gomes Duarte - A Santa Casa da Misericórdia de Mértola (1674-1834). Coimbra: Faculdade de Letras, 2008. p. 78. Dis. de mestrado policopiada.

8 A nomeação de uma comissão administrativa em 1842 para a Misericórdia de Castelo Branco tinha por objectivo travar as irregularidades e a má gestão efectuadas pelas sucessivas Mesas. Consulte-se SILVA, H. Castro e - Misericórdia de Castelo Branco. Apontamentos Históricos). Castelo Branco, s. e., 1958. p. 208-210. 
Da análise da documentação enviada e das informações colhidas, resultou a dissolução da Mesa da Misericórdia em Vila Viçosa e a nomeação de uma comissão administrativa em 31 de Outubro de $1839^{9}$. O novo órgão dirigente era composto por cinco elementos, mas a sua vida foi conturbada, com saídas e entradas de homens para a governação.

As inúmeras dificuldades tidas pela comissão prenderam-se com a falta de colaboração dos antigos e dos novos mesários ${ }^{10}$, que teimavam em rejeitar este modelo que lhes tinha sido imposto. A comissão manteve-se em funcionamento até 1845 , travando imensas dificuldades, devido às dívidas existente e à falta de verbas. Neste ano, votaram a fazer-se eleições, mas depois de eleita uma Mesa com grande custo, novamente a Misericórdia entrou em conflito por ter que obedecer ao modelo imposto pelo governador civil, ou seja, seguir a estratégia da antiga comissão. Os tempos foram muito complicados e com sucessivas demissões de irmãos que se recusavam a ocupar os cargos. Em 1850 o modelo de gestão voltou a alterar-se com a presença de uma nova comissão administrativa que se manteve até 1865 . Durante esse período, a confraria atravessou uma das crises mais profundas. A presença da cólera em força na vila e nos arredores, a crise cerealífera em 1856, a falta de cobranças e os gastos no sector hospitalar paralisaram a instituição e manteve-se sob a ameaça de encerramento. As dívidas eram tantas que vários irmãos tiveram que recorrer ao seu bolso para pagar as contas da instituição e, como não chegou, foi preciso efectuar um empréstimo a um banco do Porto. Nunca a Misericórdia tinha passado por uma situação tão aflitiva e tão comprometedora. A Santa Casa esteve praticamente parada durante quase dois anos. A comissão reunia para nada decidir e apenas visitava as enfermarias, devido ao cuidado e rigor necessários ao combate à cólera.

Apesar das críticas sentidas em 1854 pelo Conselho de Distrito à actuação da comissão, ela enfrentou uma das piores crises da Misericórdia na década

9 Nesta data, a Misericórdia do Alandroal passou também a ser gerida por uma comissão administrativa. Consulte-se MARCOS, Francisco Sanches - História da Misericórdia do Alandroal. Alandroal: Santa Casa da Misericórdia do Alandroal, 1982. p. 53.

${ }^{10}$ Embora o modelo inicialmente pensado atribuísse à comissão apenas os actos administrativos e à Mesa a gestão do sector religioso, os mesários recusaram-se a participar nesta forma repartida de poderes, entrando em colisão com a comissão, ficando esta com todas as funções. 
de 50. Geriu-a no meio de dificuldades e sem dinheiro. A sua gestão ficou marcada pelo aumento de doentes, pela epidemia de cólera, pelo tratamento de muitos militares e pagamentos muito atrasados, foros, rendas e pensões sem serem pagos e apenas satisfeitos com enormes dilações, tendo de cortar nos ordenados dos empregados e diminuir as formas de assistência em curso.

Com novos estatutos em 1881, devido à letra morta que era feita sobre os de 1618, como os confrades rasgadamente assumiam, a Misericórdia conheceu tempos mais serenos, embora com eleições marcadas por lutas violentas entre apoiantes dos partidos regenerador e progressista e com uma intervenção muito forte do administrador do concelho nos seus assuntos internos. A Misericórdia estava dividida pelos partidos, como esteve durante os anos 30 e 40 entre liberais e absolutistas.

A grave situação vivida com a crise financeira de 1891 e o corte nos juros das inscrições de dívida pública no ano seguinte desfalcaram a instituição. Os abusos, os incumprimentos, a subida dos preços dos produtos, a inflação e a falta de dinheiro tornaram a Misericórdia numa instituição pouco atractiva, conhecendo-se demissões de membros que estavam em desacordo com o rumo que esta seguia. Por outro lado, o tribunal da Junta de Distrito agia contra os dirigentes obrigando-os a pagar multas pelo incumprimento dos orçamentos. Enfim, restos de um século muito tumultuoso que deixou a Misericórdia à beira do abismo uma vez mais.

As eleições de 1897 foram novamente problemáticas. Nas primeira e segunda reuniões não houve quorum, tendo sido dado conhecimento ao administrador do concelho da ocorrência para saber como proceder, uma vez que as possibilidades estatutárias estavam esgotadas. Em consequência foi nomeada uma comissão administrativa, e sob a ameaça da Santa Casa ser dissolvida, o governador civil determinou que esta se reunisse em Assembleia Geral para alterar os estatutos e, desta forma, prevenir-se para ocasiões em que não houvesse eleições por falta da comparência dos irmãos. Aparentemente o que estava em causa era a falta de irmãos para constituir a Mesa, mas na verdade para além deste ponto muitos outros foram alterados nos estatutos de 1881, provando que era necessário proceder a outras mudanças. Por outro lado, as condenações do tribunal da Junta de Distrito em 1902, dos dirigentes desde 1894 a 1897, provam as irregularidades existentes e a falta de condições de governabilidade de uma instituição à 
beira da falência. Depois de 1902 voltou-se ao regime anterior e as Mesas eleitas deram sequência aos destinos da confraria até à República, embora num contexto de grande depressão e crise financeira.

Vulnerável em todos os campos, a Misericórdia tornou-se durante a Monarquia Constitucional um terreno fértil para os grupos e homens ambiciosos que desejavam servir-se deste patamar de poder para acumular prestígio local. As lutas políticas e a debilidade financeira em que esta se encontrava facilitaram estas condições, contribuindo para maior ruína e descapitalização da instituição.

\section{Governar uma Casa com fracos recursos}

Como bem refere Maria Antónia Lopes, as mudanças trazidas pelo Liberalismo a estas instituições decorrem de dois planos distintos: os cidadãos passaram a ter direito à assistência, enquanto o poder central se arrogava do direito de intervir mais frequentemente procurando produzir melhor efeito ${ }^{11}$.

O pedido da relação de bens em 1828 pelo governador civil de Évora estava já associado à necessidade do Estado conhecer, como já referimos, melhor a extensão dos bens das instituições, bem como as obrigações que lhe estavam associadas ${ }^{12}$.

A análise dos livros de receita e despesa, bem como o compromisso foram novamente solicitados com urgência em 1835 pelo administrador do concelho. Curiosamente, num rol de livros enviados ao governador civil de Évora apenas se encontrava um do século XIX. Todos os restantes eram tombos feitos entre os séculos XVI e XVIII ${ }^{13}$.

${ }^{11}$ Consulte-se LOPES, Maria Antónia - As Misericórdias de D. José ao final do século XX. In PAIVA, José Pedro (coordenador científico) - Portugaliae Monumenta Misericordiarum. vol. I..., 2002, p. 86.

12 Arquivo Distrital de Évora (doravante ADE), Fundo da Provedoria da Comarca, Relação de todos os bens que esta Santa Caza da Mizericordia de Villa Viçoza actualmente, 1828 , não paginado.

13 AMVV, Fundo da Misericórdia, Livro de actas 1823-1839, fls. 28v.-29. 
A tarefa do administrador do concelho não era fácil, porque se via confrontado com muitas resistências. Queixava-se Caetano José Alves de Araújo, em 1835, ao governador civil que lutava

“[...] contra difficuldades inummeraveis, Muitas, hé visivel contem este negocio em si; mas outras muito maiores tenho a constatar da crença em que estão homens que figurão nas confrarias e das quais se crem proprietarios, e a taes personagens he quasi impossivel arrancar as noções com que devo encher as folhas e muito mais difficil bem conhecer os abusos que se me mandão descrever"14.

A Misericórdia estava incluída nas confrarias que o administrador do concelho referia. Também ali, os confrades mandaram os documentos a contragosto, demonstrando o seu não alinhamento com as novas directivas do Estado Liberal. Os irmãos respondiam às solicitações feitas pelo administrador do concelho tardiamente, adoptando medidas dilatórias e, neste começo do regime Liberal, apenas após a consulta de juristas para saberem da obrigatoriedade de darem a conhecer a sua vida interna.

O pedido de mapas, livros, róis de dinheiro, de propriedades e bens era constante por parte do representante do poder central e visava conhecer os rendimentos da instituição. A Misericórdia respondia favoravelmente, mas deixava transparecer algum incómodo. Esta política sentia-se em todas as Santas Casas e tinha como objectivo um maior controlo por parte do Estado Liberal, que não apenas as geria com homens afectos ao seu poder político, como procurava medir a sua capacidade de contribuição para o Estado.

À complicada situação financeira da Misericórdia após a guerra das Laranjas e as invasões francesas, sucederam-se anos difíceis com as guerras civis. O estado das finanças do país era muito gravoso, em virtude dos custos dos conflitos e dos empréstimos avultados que foi necessário contrair para lhe fazer face, tendo-se agravado fortemente a dívida pública nacional.

${ }^{14}$ ADE, Fundo do Governo Civil, cx. 1013, Correspondência 1835, documento avulso, não paginado. 
À situação financeira do tesouro público, juntava-se a instabilidade política, que em nada favorecia o quotidiano das instituições e da população ${ }^{15}$.

A Santa Casa reconhecia graves problemas e alguma desordem no sector das cobranças e não conseguia efectuar os pagamentos. Recorria ao tribunal para obrigar os foreiros a pagar, procedia a alguns perdões, mas como estava quase totalmente dependente das cobranças dos inúmeros foros que possuía, o desgaste era enorme e não dava descanso a ninguém. $\mathrm{O}$ administrador do concelho cansava-se a dar ordens expedidas pelo governador civil, a Misericórdia recriava formas de conseguir arrancar o dinheiro e os géneros aos foreiros ${ }^{16}$, mas com gastos cada vez maiores no sector da saúde e sem o financiamento da Casa de Bragança, não apenas teve de reduzir ao máximo as despesas, cortando no salário dos empregados, no número de doentes e nas festas realizadas, como ficou praticamente paralisada durante alguns anos em meados do século ${ }^{17}$.

Os mesmos ecos de penúria eram sentidos na Câmara que também se desdobrava em esforços para conseguir ajudar os mais necessitados do concelho, sobretudo em épocas de carestia e de doença.

O dinheiro que ia chegando à Santa Casa era canalizado de imediato para efectuar pagamentos, quer aos funcionários, quer aos fornecedores. A inexistência de um fundo de maneio no cofre fazia com que o numerário entrasse e saísse com muita rapidez, deixando novamente desprevenida a instituição. Foi esta necessidade que levou a Santa Casa em 1841 a solicitar a D. Maria II autorização para poder vender quatro títulos de dívida pública sem juros, no valor de 2.369.716 réis para, com o seu rendimento, poder fazer face a várias despesas ${ }^{18}$.

${ }^{15}$ Para este assunto consulte-se SILVA, António Martins - A vitória do Liberalismo e a instabilidade constitucional: cartismo, setembrismo e cabralismo. In MATTOSO, José (dir.) - História de Portugal. Quinto volume. Lisboa: Círculo de Leitores, 1993, p. 99-100.

${ }^{16}$ Nesta altura, mandava o seu procurador às feiras onde sabia estarem presentes os seus devedores, procurando cobrar os foros e as rendas em dívida.

${ }^{17}$ AMVV, Fundo da Misericórdia, Livro de actas 1839-1847, fl. 8v. Os problemas que surgiam com as várias propriedades eram muitos e de diferente índole. Em 1837 em virtude da morte de um foreiro, um seu irmão ficou com a parte que este tinha de uma propriedade, sendo, no entanto, necessário que a Santa Casa o reconhecesse como tal. Vária, documento avulso não paginado.

${ }_{18}$ A resposta enviada pelo governador civil de Évora foi favorável, tendo mesmo afirmado considerar a atitude justa, para a Casa poder acorrer às muitas despesas da sua 
Para manter as portas abertas, irmãos e funcionários iam emprestando dinheiro à instituição, uma vez que as cobranças não aconteciam e a morosidade da justiça impedia execuções com a rapidez que a confraria necessitava. Por outro lado, cerravam-se fileiras com o exército que não pagava os tratamentos dos militares com a celeridade que o cofre da Misericórdia precisava, obrigando-a a uma correspondência contínua e muito desgastante entre o comandante do regimento de cavalaria $n^{\circ} 3$, que tinha sede em Vila Viçosa, os pagadores de Elvas e de Évora, o governador civil, a quem se pedia intercessão para acelerar o processo, e o ministro da Guerra. Enfim, um bater de portas interminável que pouco resolvia, mas que não deixava descansados todos os que amiudadamente recebiam os ofícios da Santa Casa. Mas porque não pagava o exército? Nem sempre as razões foram clarificadas, mas por várias vezes, o pagador da $7^{\text {a }}$ divisão de Évora assumiu a falta de fundos no cofre do Estado, informando despacho favorável, logo que possível. De nada valia esta resposta à confraria e não se satisfazendo com ela, porque tinha anos de atraso nos pagamentos, a Misericórdia reiniciava a peregrinação e com novos dados, porque as dívidas iam crescendo com a continuada cura de militares, batia novamente às portas dos órgãos do Estado para não encerrar as suas.

A situação de Misericórdia reflectia o estado a que o reino tinha chegado. A mobilização de recursos para fins bélicos destinados primeiro ao combate às invasões francesas e depois à pacificação do reino, aquando das guerras civis, terá contribuído para a sua não aplicação no sector produtivo e marcado toda a primeira metade do século XIX. A acumulação do défice público empurrou o reino para a contracção de empréstimos no exterior, em condições nada benéficas para Portugal ${ }^{19}$.

A Misericórdia foi obrigada a contrair um empréstimo de um conto de réis, como já referimos, para pagar a dívida passiva, porque já não tinha fornecedores que adiantassem os produtos. A dívida passiva da Santa Casa era, em 1856, de 2.501.289 réis e a dívida activa de 1.987 .488 réis.

responsabilidade. ADE, Fundo do Governo Civil, cx. 987, Documentos de despesa de 1839, não paginados.

${ }^{19}$ Veja-se MATA, Maria Eugénia - As crises financeiras no Portugal Contemporâneo. Uma perspectiva de conjunto. In MATOS, Sérgio Campos (org.) - Crises em Portugal nos séculos XIX e XX. Lisboa: Centro de História da Universidade de Lisboa, 2002, p. 33-34. 
O orçamento procurava suportar o descalabro das contas no elevado número de doentes que afluía ao hospital e na carestia de todos os géneros, enquanto a comissão administrativa afiançava assistir com mágoa a esta situação, dizendo não a poder resolver no futuro próximo, mas garantia tudo fazer para resolver o possível ${ }^{20}$.

Não foi fácil convencer o tribunal da Junta de Distrito da necessidade da contracção do empréstimo. Foi preciso justificar, mandar elementos comprovativos das dívidas, livros e papéis para o empréstimo ser autorizado. Os juros eram muito elevados e talvez temesse a falta de capacidade da instituição para o poder pagar. Depois deste, outros se seguirão para fazer face às dívidas que transitaram para tribunal.

Com a lei de desamortização de 1866 a Misericórdia serenou um pouco, porque desapareceu a pressão que mantinha sobre os foreiros, embora a posse de foros e rendas se mantivesse, mas em número muito reduzido quando comparado com os existentes até então. Com o dinheiro obtido com a venda em hasta pública das propriedades foram compradas inscrições de dívida pública, cumprindo a lei, e a Misericórdia passou a contar com os juros bianuais dessas inscrições. Era um rendimento seguro, a que se juntaram alguns legados, mas também acções judiciais contra a falta de pagamento da Santa Casa quer aos irmãos que emprestavam dinheiro, como era o caso do tesoureiro, quer aos fornecedores.

Uma outra crise foi vivida entre 1868 e 1871 . Novamente, o agravamento da pobreza se reflectia na Misericórdia que desde há muito agonizava. Dificuldades de cobrar os foros e rendas, dívidas acumuladas e, consequentemente, mal-estar na Santa Casa. Despesas que cresciam sem serem pagas, salários atrasados, pagamentos aos fornecedores em lista de espera, enfim, uma situação de grande aflição financeira, que uma vez mais punham em causa a sobrevivência da instituição.

Neste período, o decréscimo das receitas no cofre do Estado, assim como as dificuldades nas cobranças dos impostos, terão contribuído para agravar a situação financeira do Estado $^{21}$. A agravar esta situação juntava-se uma

\footnotetext{
${ }^{20}$ ADE, Fundo do Governo Civil, cx. 983, Orçamento de receita e despesa 1856-1857, documento avulso, não paginado.

${ }^{21}$ MATA, Maria Eugénia - As crises financeiras no Portugal Contemporâneo..., cit., p. 39.
} 
crise política que se estendeu entre $1868-1871^{22}$. A este período seguiu-se um outro de alguma acalmia, mas a situação de Misericórdia continuava muito débil.

Aúltima década do século XIX e a primeira do seguinte foram marcadas pela penúria que se instalou novamente na confraria. $\mathrm{O}$ golpe mais duro foi sofrido em 1892 com a redução de 30\% nos juros das inscrições de dívida pública. Os mesários, preocupados por ser este o seu principal rendimento para fazer face ao que consideravam ser uma "elevadissima despesa feita em medicamentos com os doentes pobres socorridos pela Misericordia fora do hospital", decidiram, por unanimidade, socorrer somente fora do hospital os doentes que fossem tratados pelos facultativos da $\mathrm{Casa}^{23}$. Já no ano anterior, a Mesa tinha mostrado grande preocupação com os gastos efectuados com os medicamentos dos doentes que se tratavam no seu domicílio. Os cortes eram inevitáveis e decorriam da asfixia financeira da Misericórdia.

Esta situação decorria do colapso em que se encontravam as finanças públicas e o sistema bancário nacional que arrasaram as finanças da instituição.

O Banco de Portugal viu-se impossibilitado de pagar os juros da dívida pública e abandonou o "padrão-ouro" em vigor desde 1852. Em consequência, o governo foi obrigado a reduzir os juros da dívida pública em 30\%, em 1892. "O Estado, que deixou de conseguir financiar-se pela captação de ouro dos particulares, passou a recorrer à emissão de papel-moeda, o que significava pagar as despesas correntes com notas de valor fictício, declarando o seu curso forçado, aumentando desta forma as tendências inflacionistas"24.

${ }^{22}$ Para um maior desenvolvimento sobre este assunto consulte-se SILVEIRA, Luís Nuno Espinha da; FERNANDES, Paulo Jorge - D. Luís. Lisboa: Círculo de Leitores, 2006, p. 161-186.

${ }^{23}$ AMVV, Fundo da Misericórdia, Livro de actas 1882-1896, fls. 158-158v.

${ }^{24}$ Para este assunto leia-se FERNANDES, Paulo Jorge - Política económica. In LAINS, Pedro; SILVA, Álvaro Ferreira da (orgs.) - História Económica de Portugal 1700-2000. O século XIX. Lisboa: Instituto de Ciências Sociais, 2005, p. 413-414. Para uma análise mais aprofundada da crise de 1891 consulte-se LAINS, Pedro - A crise financeira de $1891 \mathrm{em}$ seus aspectos políticos. In MATOS, Sérgio Campos (org.), Crises em Portugal nos séculos $X I X$ e $X X$..., p. 57-60; MATOS, Sérgio Campos - A crise do final de Oitocentos em Portugal. In Matos, Sérgio Campos (org.) - Crises em Portugal nos séculos XIX e XX..., p. 100-104. 
A crise instalou o pânico e a descrença no sistema bancário e obrigando, em 1896, a uma maior intervenção do Estado neste sector ${ }^{25}$.

Alei de 26 de Fevereiro de 1892 desferiu um rude golpe nas Misericórdias ao reduzir em $30 \%$ os juros das inscrições de dívida pública, onde tinham investido os seus capitais ${ }^{26}$. O embate desta lei nas diferentes Misericórdias está ainda por estudar, recorde-se, aliás, o imenso caminho que é necessário percorrer para se conhecer o funcionamento destas instituições nos séculos XIX e XX, todavia, numa Santa Casa que desde há muito lutava com gravíssimas dificuldades, sentir uma redução de 30\% nas suas receitas foi brutal e desde logo a impediu de continuar a ter farmácia, sendo obrigada a arrendá-la. Mas as consequências fizeram-se sentir a outros níveis. Sem se conseguir erguer, a Misericórdia, para não encerrar, foi novamente gerida por uma comissão administrativa, mantendo-se numa agonia profunda até à República com vários orçamentos suplementares por ano, vivendo de subsídios do Estado e de particulares, por não conseguir organizar as suas finanças.

\section{A beneficência da Santa Casa}

Se compararmos a assistência praticada pela Misericórdia de Vila Viçosa na Época Moderna com a existente durante a Monarquia Constitucional, verificamos que ela se reestruturou, sendo, simultaneamente, reduzida.

A Santa Casa foi ao longo do século XIX e primeira década do XX, e em virtude das condições muito difíceis em que se encontrava, deixando de praticar algumas obras de beneficência. Este afunilamento ficou a dever-se às duras condições de sobrevivência que conheceu no período em estudo.

${ }^{25}$ NUNES, Ana Bela; VALÉRIO, Nuno - Moeda e bancos. In LAINS, Pedro; SILVA, Álvaro Ferreira da (orgs.) - História Económica de Portugal 1700-2000. O século XIX..., p. 294-298.

${ }^{26}$ Leia-se para este assunto LOPES, Maria Antónia - As Misericórdias de D. José ao fim do século XX, cit., p. 89. 
Mau grado a laicização da assistência, as práticas de caridade das Misericórdias, de outras confrarias e da Igreja, permaneceram ao lado das de instituições laicas e das exercidas pelos particulares durante este período ${ }^{27}$.

Em primeiro lugar, deve ter-se em consideração a ajuda aos aposentados ${ }^{28}$. A Santa Casa deixou de aceitar pessoas com este estatuto em 1851, embora formalmente só o tenha declarado em 1859, o mesmo se passou relativamente a outras esmolas enviadas a pobres, as quais terminaram em 1854. As ajudas mandadas para a criação de crianças de leite desaparecem, em 1868. As cartas de guia foram suspensas em 1856, mas permaneceram, a muito custo até 1860 . Na teoria elas continuaram a existir, mas não há menções sobre a sua passagem a partir desta data. Esta prática foi posteriormente retomada e o compromisso de 1881 confere ao provedor a faculdade de as passar, excepto para Lisboa ${ }^{29}$. A regularidade foi estabelecida em 1886, quando a Santa Casa passou a contratar um homem para conduzir os doentes com cartas de guia para as localidades vizinhas do Alandroal, Juromenha e Borba, circunscrevendo o auxílio destes pobres a estas terras, uma vez que nelas podiam renovar o pedido a uma instituição congénere. A partir de 1897 não há mais sinais da passagem destes documentos.

A festividade da semana santa manteve-se, mas as esmolas que se costumavam entregar na quinta-feira aos pobres estiveram suspensas entre 1839 e 1845, sendo posteriormente retomadas até à República, embora tivessem sofrido cortes substanciais e permanecessem, em parte, devido ao pagamento dos mesários e dos particulares. Os ofícios pelas almas dos irmãos, benfeitores e sepultados no cemitério da Casa também se mantiveram até à República, apesar do sector religioso ter sofrido uma enorme redução e assistido à perda de influência.

A Misericórdia ganhou mais um grupo de pobres, quando no século XIX foi confrontada com a necessidade de enviar uma quantia de dinheiro à Câmara para a despesa com as amas dos expostos. Fê-lo sempre com grande

${ }^{27}$ Leia-se a propósito TEIXEIRA, Maria Elvira - Assistência. Do fim da Monarquia ao Estado Novo. In AZEVEDO, Carlos Moreira (dir.) - Dicionário de História Religiosa de Portugal. Lisboa: Círculo de Leitores, 2000. p. 149.

${ }^{28}$ A Misericórdia recebia alguns idosos pobres, que recolhia, e aí permaneciam até à morte.

${ }^{29}$ AMVV, Fundo da Misericórdia, Compromisso da Misericordia de Villa Viçosa, 1881, não paginado. 
incómodo, porque vivia uma situação financeira aflitiva, mas também porque não se considerava obrigada pela lei. Conseguiu um corte substancial no montante que lhe tinham inicialmente imposto e ainda na década de 40 do século XIX deixou de enviar essa quantia à Câmara.

A assistência aos presos também se manteve, ainda que no novo enquadramento legislativo. A Misericórdia continuou a cumprir o ritual de enviar o jantar aos encarcerados no dia de quinta-feira santa, mas procurava passar responsabilidades para outros poderes quando era contactada para maiores contribuições.

Apesar das dificuldades sentidas, a Misericórdia continuou a combater a doença, a pobreza e a ajudar na morte, na invalidez, na orfandade e na velhice. Só quando não foi possível, restringiu a sua prática e concentrou-se quase somente no tratamento à doença e na ajuda a alguns pobres na semana santa. Confrontada com necessidades várias e perante a impossibilidade de as satisfazer, a Santa Casa assumiu preferencialmente a função de combater a doença e focalizou toda a sua atenção no hospital. Os irmãos assumiam mesmo que essa era a sua principal finalidade, deixando para segundo plano uma vertente a que sempre tinham dado relevo, a assistência domiciliária. Esta forma de ajuda permaneceu, mas muito secundarizada. Foi no hospital que se colocaram todos os cuidados e nele se gastou quase todo o dinheiro que existia no cofre.

Contrariamente ao verificado em outros hospitais, o de Vila Viçosa só conheceu o primeiro regulamento em $1840^{30}$. Em 1852 foi elaborado outro regulamento que complementava o de 1840 e vinha na sequência das obras efectuadas nas enfermarias.

O regulamento procurou dotar o hospital de normas mais adaptadas às exigências de uma unidade de saúde reformada ${ }^{31}$. Trata-se de um corpo normativo mais alargado que o elaborado em 1840 e prova que o anterior não era suficiente, nem estava adequado às novas exigências da instituição. Por outro lado, não deixa de ser interessante verificar que entre 1510 e

${ }^{30}$ O hospital de Setúbal teve o primeiro regimento em 1779, seguindo-se outros no século XIX. Veja-se ABREU, Laurinda - Memórias da alma e do corpo. A Misericórdia de Setúbal na Modernidade. Viseu: Palimage Editora, 1999, p. 391-392.

${ }^{31}$ Para o efeito foi necessário proceder a um orçamento suplementar. ADE, Fundo do Governo Civil, cx. 983, Documento avulso, não paginado. 
1840 o hospital funcionou sem qualquer regulamento e que no século XIX, num espaço de 12 anos, se elaboraram dois. Esta produção normativa se, por um lado, evidenciava a necessidade de regras, apontava também para o relevo conferido ao sector da saúde e à importância dada pela Santa Casa ao hospital, principal actividade da instituição.

As condições financeiras da confraria foram responsáveis pelas medidas tomadas ao longo dos anos pela Santa Casa no sentido de diminuir o número de doentes internados e os que se tratavam em suas casas. O crivo apertava-se sempre que crescia o número de internados, pedindo-se atestados aos párocos sobre a pobreza dos interessados e ordenando-se aos profissionais de saúde o despedimento de todos os que já não corriam perigo de vida. Em 1858, incapaz de fazer parar a escalada das despesas, foi deliberado não aceitar mais de 20 doentes no hospital: 12 de medicina e oito de cirurgia, tendo sido pedido ao médico e ao cirurgião o cumprimento desta medida. O médico João da Cunha Rivara e o cirurgião José António da Veiga prometeram respeitar a resolução tomada ${ }^{32}$, embora em alguns momentos estes limites tenham sido ultrapassados.

Com a restrição de ingresso no hospital, aumentaram os pedidos de tratamento ao domicílio, bem como as queixas sobre o tratamento recebido, facto que levou a comissão administrativa a escrever ao pároco de São Bartolomeu $^{33}$, explicitando os cuidados de saúde prestados aos domiciliados ${ }^{34}$.

No final de 1864 foi acordado que se tratariam apenas 15 doentes no hospital de ambos os sexos, subtraindo cinco ao número anteriormente fixado. Os argumentos nada traziam de novo: inexistência de fundos para tratar mais enfermos. A medida foi tomada na presença dos facultativos do hospital, responsabilizando-os pela gestão e admissão dos doentes. Foi-lhes pedido rigor e minúcia na aceitação de enfermos, bem como a não ultrapassagem deste número sem "a necessidade absoluta o exigir" 35. A falta de recursos afectou vários hospitais neste período. Em Coimbra, a escassez

${ }^{32}$ AMVV, Fundo da Misericórdia, Livro de actas 1857-1860, fls. 9v.-10.

${ }^{33}$ A Misericórdia e o hospital estavam localizados na paróquia de São Bartolomeu.

${ }^{34}$ AMVV, Fundo da Misericórdia, Livro de registo dos oficios do copiador expedidos pela Misericordia 1857-1867, fl. 16.

${ }^{35}$ AMVV, Fundo da Misericórdia, Livro de actas 1863-1868, fl. 22. 
de meios foi responsável por medidas tendentes a reduzir as despesas ${ }^{36}$. De forma abrupta, a Santa Casa de Vila Viçosa ia descendo o volume de internados, demonstrando as dificuldades com que se confrontava para manter o hospital aberto.

A Misericórdia recebia dois tipos de enfermos: os que podiam pagar o seu tratamento, sendo curados em quartos particulares e os que eram tratados gratuitamente, por falta de condições económicas. Entre os primeiros, integravam-se as pessoas de posses, os militares, os mineiros da mina do Bugalho e alguns alienados que o hospital recebeu ao longo do período em estudo. Era um grupo variado que no princípio do século XX incluiu também os polícias destacados na vila. Todavia, os principais pagadores eram os militares, embora o dinheiro tardasse a chegar.

O compromisso de 1881 estabelecia o preço de 240 réis diários para os que estavam internados nas enfermarias e 400 réis para os instalados em quartos particulares. Todavia, o regulamento advertia para a necessidade de evitar vexames às pessoas que se viam obrigadas a pagamento e estavam impossibilitadas de o honrar, em virtude das dificuldades que passavam. A estes, segundo o compromisso, bastava a infelicidade da doença ${ }^{37}$. Embora obrigatório, o pagamento devia ser efectuado com moderação, não estigmatizando os incapazes de o fazerem. Como se constatou ao longo do período em estudo, alguns doentes deveriam pagar a conta do seu internamento, mas como não tinham dinheiro, era com os seus bens imóveis que a confraria se via ressarcida, embora nem sempre esta solução fosse do agrado dos herdeiros.

Os hospitais eram sorvedouros de dinheiro e em Vila Viçosa constituía a principal fonte de despesas, todavia, era também uma interessante fonte de receitas, à semelhança, aliás, do que se passava desde o século XVIII.

Depois de serem aceites, os doentes estavam obrigados a cumprirem as regras internas e a adequarem o seu comportamento ao exigido. Em 1854 estabeleceu-se que depois de internados, os doentes deviam cortar o cabelo, fazer a barba e tomar banho de água quente, quando o seu estado de saúde

${ }^{36}$ Consulte-se LOPES, Maria Antónia - Os pobres e os mecanismos de protecção social em Coimbra de meados do século XVIII a meados do XIX. In A História Tal e Qual se Faz. Lisboa: Colibri/Faculdade de Letras da Universidade de Coimbra, 2003. p. 101.

${ }^{37}$ AMVV, Fundo da Misericórdia, Compromisso de 1881, não paginado. 
o permitisse ${ }^{38}$. A preocupação com a higiene era agora maior e necessária, sobretudo junto dos grupos mais desfavorecidos da população que raramente cuidavam da higiene corporal. Esta medida era tomada nas vésperas do anúncio público da cólera na vila, tornando-se urgente proceder a medidas de higiene pessoal e colectiva.

Com problemas internos graves, a Misericórdia viu-se ainda obrigada a abrir mais uma frente de batalha na década de 70 de Oitocentos com o hospital de São José de Lisboa, devido aos doentes alienados que seguiam de Vila Viçosa para o hospital de Rilhafoles. Negando-se a assumir as contas enviadas pelo mordomo-mor do hospital de São José, a Misericórdia alentejana escudava-se em razões pouco sustentadas, alegando não ter passado cartas de guia para Lisboa desde 1852, mas o que é certo é que vários doentes alienados foram remetidos para Rilhafoles nas décadas de 60 e 70 e a Misericórdia foi obrigada a pagar as despesas, por ordem régia. De nada lhe valeu o tom sarcástico com que várias vezes tratou o mordomo-mor do hospital da capital e mesmo as dúvidas lançadas de forma intencional sobre a sua gestão. Pagou muito a custo e de forma parcelar, como lhe faziam os seus devedores, até à República, demonstrando a dificuldade que tinha em saldar as suas dívidas.

A solução encontrada em 1897 foi nomear uma comissão administrativa, mas também esta não fez milagres e decidiu cortar nos socorros aos pobres ajudados em casa e algumas despesas com as festividades da semana santa. A Misericórdia vivia neste momento da ajuda de beneméritos: os membros da comissão administrativa, cavalheiros e senhoras que a beneficiavam na ocasião em que era novamente ameaçada pelo governador civil de ser encerrada e os seus bens distribuídos pelo asilo e por outros estabelecimentos do concelho.

A Santa Casa aguentou-se, arrastando-se sem perspectivas de poder alterar uma conjuntura que lhe era desfavorável e a penalizava fortemente. Com dívidas acumuladas, gestores acusados de fraudes e não observância da lei, quebra abrupta dos rendimentos a partir de 1892, encerramento da farmácia em 1896, por falta de farmacêuticos que quisessem permanecer na vila, devido ao baixo ordenado que lhes era pago, e consequente

${ }^{38}$ AMVV, Fundo da Misericórdia, Livro de actas 1847-1857, fl. 60. 
arrendamento após três anos, o hospital vivia tempos muito complicados no dealbar do novo século, embora se constituísse no principal eixo de beneficência da Santa Casa. A Misericórdia resumia-se praticamente ao hospital e, mesmo assim, chegou moribunda à República.

\section{Considerações finais}

Apesar dos cortes efectuados em vários sectores de actividade, a Misericórdia de Vila Viçosa ganhou a difícil luta pela sobrevivência, embora tenha chegado à República envolta em conflitos e quase falida.

Fortemente fustigada pelas mudanças políticas e pelas crises económicas e financeiras do reino, a Santa Casa ficou muito exposta às lutas políticas e, por várias vezes, se cindiu internamente. Situada no coração da Casa de Bragança, reagiu mal às inovações liberais e no final do século é clara a animosidade sentida contra os adeptos do republicanismo.

Vivendo principalmente de rendimentos de foros, rendas e pensões até à lei de desamortização de 1866, a Santa Casa esteve perto da falência sempre que a agricultura entrou em crise e surgiram epidemias. Depois, em 1892, com o corte de 30\% nos juros das inscrições de dívida pública, sofreu um golpe de morte que a tornou dependente de benfeitores, praticamente paralisada e ameaçada de insolvência.

Muito permeável a factores externos e com uma situação financeira muito frágil, o caminho encontrado para sobreviver foi o de reduzir a despesa, deixando cair progressivamente formas tradicionais de assistência e concentrando-se quase exclusivamente no hospital. 